\title{
Rising Food Prices, Food Price Volatility, and Political Unrest*
}

\author{
Marc F. Bellemare ${ }^{\dagger}$
}

August 12, 2011

\begin{abstract}
Do food prices cause political unrest? Throughout history, riots appear to have frequently broken out as a consequence of high food prices. This paper studies the impact of food prices on food-related political unrest using monthly data at the international level. Because food prices and political unrest are jointly determined, the number of natural disasters in a given month is used in an attempt to identify the causal relationship flowing from food prices and political unrest unrest. Empirical results indicate that between January 1990 and January 2011, food price increases appear to have led to increased political unrest, whereas food price volatility has been associated with decreases in political unrest. These findings are consistent with those of the applied microeconomics literature on the welfare impacts of food prices.

Keywords: Food Prices, Price Volatility, Development Policy, Food Riots, Political Unrest

JEL Codes: D74, O11, O13, Q11, Q34
\end{abstract}

*I thank Gani Aldashev, Chris Barrett, Samuel Bazzi, Phil Cook, Jay Hamilton, Marc Jeuland, Anirudh Krishna, Kyeong Ho Lee, Gabriel Power, Cyrus Samii, and Satoru Shimokawa for helpful comments and suggestions as well as Kevin Fishner for excellent research assistance. All remaining errors are mine.

${ }^{\dagger}$ Assistant Professor, Sanford School of Public Policy, Duke University, Durham, NC 27708-0312, United States, Telephone: +1 (919) 613-9382, Facsimile: +1 (919) 681-8288, Email: marc. bellemare@duke.edu. 


\section{Introduction}

Can food prices cause political unrest? Economic theory is quite clear on the subject. Take two households who are net consumers of food and who differ only in their respective levels of income. If food is a normal good (that is, if the demand for food is increasing in income), the impact of a price change on welfare will be felt comparatively more by the poorer of those two households, who devotes a higher share of its budget to food consumption. In developing countries, poor households often allocate more than 50 percent of their budget to food purchases-a proportion that increases directly as a result of increases in food price increases. For a large enough increase in the price of food, the welfare loss incurred by the poor may threaten their very subsistence, which in turn may push them toward desperate measures.

But so much for the theory. Do food prices actually cause political unrest? Throughout history, riots appear to have frequently broken out as an ostensible consequence of high food prices in areas with high concentration of poor households. Since the turn of the millennium, the world has experienced two major food crises. The first one took place in 2008. Although food prices increased by only 3 percent between January 2007 and December 2008, they increased by 51 percent between January 2007 and March 2008. ${ }^{1}$ This rise in food prices was associated with food riots in several developing and emerging countries across Africa, Asia, Europe, and the Americas (Schneider, 2008; Bush, 2010). ${ }^{2}$ The second food crisis,

\footnotetext{
${ }^{1}$ All the food price figures in this paper are from the Food and Agriculture Organization (FAO) of the United Nations' Food Price Index, available at http://www.fao.org/worldfoodsituation/wfs-home/ foodpricesindex/en/.

2The expressions "political unrest" and "food riots" are used interchangeably throughout this paper. The
} 
which began at the end of 2010 and saw food prices increase by 40 percent between January 2010 and February 2011, has culminated by the current famine in the Horn of Africa and is still ongoing. Once again, a rapid rise in food prices was associated with political unrest throughout the world, but it was perhaps most prominently associated with the so-called Arab Spring of 2011-a series of events which began with food riots in Algeria and in Tunisia in early January 2011 (Ciezadlo, 2011), and which led to the collapse of the Ben Ali regime in Tunisia and of the Mubarak regime in Egypt. Although it is not possible to assert that food prices caused the Arab Spring - the correlation between food prices and political unrest does not mean that one causes the other - this does raise the question of whether food prices cause political unrest.

To further complicate the relationship between food prices and political unrest, there appears to be a considerable amount of confusion in the media and among policy makers in discussions of how food prices may cause political unrest. For some, this means rising food prices. Economists have long known (see, for example, the seminal work of Deaton, 1989) that an increase in the price of a commodity, although it increases the welfare of the households who are net sellers that commodity, decreases the welfare of the relatively many more households who are net buyers of that commodity, and there are numerous instances of political unrest associated with rising food prices throughout history (Rudé, 1964; Walton and Seddon, 1994; Schneider, 2008; Bush, 2010).

For others, this means food price volatility. At the end of January 2011, French president reader should keep in mind, however, that the two are generally not synonyms-political unrest encompasses social movements other than food riots, such as labor strikes, coups, and so on. 
Nicolas Sarkozy declared that during his tenure as head of the G-20, he would make price volatility his top priority, going so far as to say that "if we don't do anything, we run the risk of food riots in the poorest countries" (Reuters, 2011). The Brookings Institution noted in March 2011 that "the crux of the food price challenge is about price volatility rather than high prices per se (...) [i]t is the rapid and unpredictable changes in food prices that wreak havoc on markets, politics and social stability" (Kharas, 2011). Likewise, the FAO had convened its High-Level Panel of Experts on Food Security and Nutrition at the end of 2010 with the explicit goal of exploring the causes and consequences of food price volatility. But not only has food price volatility not significantly increased in recent years (Gilbert and Morgan, 2010), ${ }^{3}$ food price volatility has been found empirically to affect rural households in a developing country as follows: it decreases the welfare of net producers of food, who need to commit resources to production long in advance of realized prices, but it leaves net consumers of food largely unaffected (Barrett, 1996; Bellemare et al., 2011).

Given that food prices has occupied a considerable place in the development policy discourse over the last few years, this paper studies the relationship between food prices and political unrest. ${ }^{4}$ More specifically, this paper looks at two research questions. It first looks at whether the relationship between food price levels and political unrest is causal. Because food prices and political unrest are jointly determined, however, the incidence of natural disasters (i.e., the number of unpredictable shocks to both the supply and demand of food)

\footnotetext{
${ }^{3}$ Likewise, Jacks et al. (2011) show that although commodity prices are more volatile than the prices of manufactured goods, commodity price volatility has not increased significantly over the last 300 years.

${ }^{4}$ A precise definition of how "political unrest" is defined in this paper is provided in section 4, when discussing how each variable retained for analysis was measured.
} 
is used as an instrumental variable in an attempt to make the food price level exogenous relative to political unrest. The idea behind this empirical setup is that a natural disaster that occurs in one part of the world affects world food prices, and a change in food prices makes it more or less likely to observe food riots in another part in the world in the short term. Indeed, this is what is thought to have happened in late 2010 and early 2011, when floods in Australia and droughts in Africa raised food prices, which then led to political unrest in North Africa.

Second, this paper looks at the relationship between food price levels and food price volatility on the one hand and on political unrest on the other hand in an attempt to contribute to the debate between those who argue that rising food prices cause political unrest and those who argue that food price volatility causes political unrest.

Using monthly data at the international level, the empirical results indicate that between January 1990 and January 2011, rising food prices have led to increased political unrest, whereas food price volatility - defined here as the standard deviation of the food price series over the previous three or six months - has actually been associated with decreases in political unrest. This is not to say that food price volatility is desirable, however, as episodes of rising food prices are generally positively correlated with episodes of increased food price volatility, and because food price volatility today can lead to decreased output - and thus higher food prices - in the future (Clapp, 2009; Naylor and Falcon, 2010). What this means, however, is that it is difficult to make the case, as so many already have in the media and in policy circles, that food price volatility causes political unrest. 
Generally speaking, this paper is part of a small literature at the intersection of economics and political science studying the economic determinants of riots (DiPasquale and Glaeser, 1998; Bohlken and Sergenti, 2010). This paper is closest in spirit to a recent paper by Arezki and Brückner (2011), who look at the relationship between food prices and political instability. The analysis in this paper differs from that of Arezki and Brückner in a few ways. First, this paper relies on monthly food price data, whereas Arezki and Brückner use annual food price data. The advantage of using monthly data is that this allow capturing short-term (i.e., month-to-month) price fluctuations. This is important given that people are more likely to react to short-term (i.e., monthly) food price changes than they are to react to long-term (i.e., annual) price changes. The disadvantage of using monthly food price data, however, is that official monthly data on political unrest are not available. Arezki and Brückner's advantage is that they can rely on the PRS Group's International Country Risk Guide data for their measures of political unrest, whereas this paper relies on a proxy measure of political unrest constructed from media sources. The data limitations inherent to either approach highlight the trade-off between the monthly, international approach in this paper and Arezki and Brückner's annual, country-level approach. As such, the analyses in this paper and in Arezki and Brückner's are complementary.

Given that the world economy is increasingly integrated, an ever higher volume of food commodities are being traded. This means that food prices are increasingly correlated, and so episodes of rising food prices - which are expected to occur more frequently given the threat to agricultural productivity posed by climate change (Lobell et al., 2011) - will be 
increasingly correlated across countries. Thus, if there is a causal relationship between food prices and political unrest, this could ultimately mean that episodes of political unrest will occur simultaneously across countries, which means that food prices have the potential to cause irreversible damage to the health of affected populations by depriving them of nutrients and causing them to be malnourished (Haddad et al., 1999; Webb, 2010) as well as to be a destabilizing geopolitical force. Of course, the results in this paper do not imply that food prices are the only cause of food riots. Goldstone (1982) notes that food riots usually break out when high food prices are accompanied by widespread unemployment. Likewise, the results in this paper do not imply that rising food prices inevitably cause political unrest. Rather, the objective of this paper is to show that food prices can have a causal impact on political unrest in certain cases.

The rest of this paper is organized as follows. Section 2 provides some background by discussing food riots throughout history. In section 3, the empirical framework is laid out and explained. Section 4 discusses the data and presents descriptive statistics. In section 5 , the empirical results are presented and discussed, along with the results of several robustness checks. Section 6 concludes.

\section{Food Riots in History}

Throughout history, food riots have been frequent. They are thought to have helped bring about the French Revolution (Rudé, 1964), the fall of the Confederate States of America 
(Smith, 2011), the Russian Revolution (Wade, 2005), and the fall of the British Raj in India (Arnold, 1979). Although there are several studies of food riots in the historical and sociological literatures, there are few quantitative studies of food riots other than that by Arezki and Brückner (2011). In order to put the empirical results in this paper in their proper context, what follows is an overview of food riots in modern and contemporary history. ${ }^{5}$

The earliest such study is Rudé's (1964) investigation of social movements - food riots, labor disputes, and political protests - in France and England between 1730 and 1848. Rudé begins with the "disastrous harvest and famine of 1709" (p.19) in France and goes on to discuss how bad harvests and other natural disasters in 1787 "stirred the whole countryside into a renewed outbreak of rebellion, which played a vital part in the revolutionary crisis of 1789" (p.20) that marked the beginning of the French Revolution. Between 1709 and 1789, however, food riots occurred in France as a consequence of bad harvests and subsequent shortages in $1725,1740,1749,1768,1775$, and 1785 . Yet until the French Revolution, food riots were not political in nature. ${ }^{6}$ Rather, rioters targeted farmers, merchants, and traders in an effort to force a decrease in food prices. This phenomenon is known to historians as taxation populaire (Tilly, 1971), i.e., a situation in which farmers, merchants, and traders pay a "popular tax" by forgoing some profit or incurring a loss as a consequence of the price ceiling imposed by rioters.

In England where, as a consequence of the Industrial Revolution, a greater share of the

\footnotetext{
${ }^{5}$ For a survey of the social science literature on riots broadly defined, see Wilkinson (2009).

${ }^{6}$ Citing Clark (1976), Walton and Seddon (1994) note that before the French Revolution, "there was no question of overthrowing the government or established order, of putting forward new solutions, or even of seeking redress of grievances by political action" (p. 29).
} 
population was composed of net consumers of food than in more rural France, Rudé notes that "[o]f some 275 disturbances that [he has] noted between 1735 and 1800, two in every three" (p.35) were food riots. Moreover, food riots tended to break out more often in the north and west than in the south and east of England given that food - more specifically, grain - was exported from the latter to the former.

A study of more recent food riots is found in Walton and Seddon (1994), who study the impact of the International Monetary Fund's (IMF) structural adjustment programs on the economies of the developing world between 1970 and the early 1990s. According to Walton and Seddon, even though food riots had largely disappeared from the political landscape after the middle of the 19th century, they reappeared in the 1970s as a consequence of an increasingly integrated world economy in which local food prices were increasingly determined by the international political economy.

Walton and Seddon note that with the exception of Ceylon's hartal in 1953, in which countrywide food riots broke out in response to the government eliminating rice subsidies, there were only few food riots between the middle of the 19 th century and the $1970 \mathrm{~s},{ }^{7}$ and the few that occurred were local, sporadic events. ${ }^{8}$ The mid-1970s saw a resurgence of food riots, however, as Walton and Seddon count 146 food riots across 39 countries in response to austerity policies imposed by the IMF's structural adjustment policies between 1976 and 1992. What began in Peru in July 1976 and Egypt in January 1977 peaked in the mid-1980s

\footnotetext{
${ }^{7}$ See Taylor (1996) for a study of some of the food riots that broke out in the first half of the 20th century.

${ }^{8}$ The food riots of 2001 in Argentina (Auyero and Moran, 2007) were also local in the sense that they did not occur in a context where food riots broke out in several countries.
} 
and ended in India in February 1992 and Nepal in April 1992. Walton and Seddon's volume includes also case studies of food riots in Latin America, Africa, as well as in the Middle East and North Africa.

The "classical" food riots studied by Rudé (1964) often took place in the countryside and involved the rural poor (i.e., individuals and households who remained net buyers of food even though they might have produced some food themselves). By contrast, the "modern" food riots studied by Walton and Seddon (1994) almost always took place in cities and involved the urban poor and the working class (i.e., individuals and households who are net buyers of food). Classical and modern food riots also differ in their targets: whereas the targets of classical food riots were local food producers suspected of price gouging and grain merchants suspected of speculating, the targets of modern food riots were supermarkets, government institutions, and symbols of foreign affluence such as luxury hotels.

While it is still too early for the history of recent food riots to have been written, Schneider (2008) provides an overview of the riots that took place across Africa, Asia, Latin America, and the Middle East during the food crisis of 2008. For each of the 25 countries in which there were food riots, Schneider provides a description of the rioting that took place, of the government's response to political unrest, and of the state of democracy. Lastly, Bush (2010) displays an admirable prescience in his discussion of the consequences of the 2008 food riots in the Middle East and North Africa. 


\section{Empirical Framework}

The contribution of this paper lies in the way it identifies the impact of food prices on political unrest. This section thus first discusses on the equations to be estimated, and then the identification strategy used in an attempt to establish the causal impact of food prices on political unrest.

The first equation to be estimated in this paper is

$$
y_{t}=\alpha_{1}+\beta_{1 f} f_{t}+\beta_{1 \sigma} \sigma_{t}+\beta_{1 y} y_{t-1}+\beta_{1 m} m_{t}+\beta_{1 \tau} \tau_{t}+\epsilon_{1 t}
$$

where the unit of observation $t$ is one month, $y_{t}$ denotes the level of political unrest in month $t ; f_{t}$ denotes the food price level; $\sigma_{t}$ denotes three-month food price volatility, i.e., the standard deviation of the price series over the months $t, t-1$, and $t-2 ;^{9,10} y_{t-1}$ denotes political unrest in the previous month; $m_{t}$ is a vector of monthly indicator variables in month $t ; \tau_{t}$ is a time trend, and $\epsilon_{t}$ is an error term with mean zero. Because food riots tend to occur in poor countries, where the average diet consists mainly of cereals, equation 1 is estimated twice: once for an index of the overall price of food, and once for an index of the price of cereals. This provides a first robustness checks on the empirical results.

The equations in this paper are estimated by ordinary least squares (OLS). Because

\footnotetext{
${ }^{9}$ Letting the three-month moving average of the price series evaluated at $t$ be $\mu_{t}=\frac{1}{3} \sum_{j=0}^{2} y_{t-j}$, the three-month standard deviation is such that $\sigma_{t}=\sum_{j=0}^{2}\left|y_{t-j}-\mu_{t}\right|$. A three-month food price volatility of zero in a given month would mean that the food price index has remained constant over the last three months.

${ }^{10} \mathrm{~A}$ robustness check is conducted in section 5 which relies instead on six-month food price volatility, i.e., the standard deviation of the price series over the months $t$ to $t-5$.
} 
Durbin-Watson tests below show that the standard errors are not serially correlated, the usual standard errors are reported. Likewise, Dickey-Fuller tests below indicate that one can reject the presence of a unit root for the dependent variable as well as for the instruments, but not for the level of food prices. In an investigation of alternative specifications for unit root tests, however, Wang and Tomek (2007) show that nominal food prices do not exhibit unit roots once structural breaks are accounted for. For this reason, and to keep the empirical specification in this paper as simple as possible, all variables in equation 1 are expressed in levels.

As was discussed in the introduction, the primary objective of this paper is to assess whether food prices cause political unrest. Because political unrest and food prices are jointly determined, however, the next section discusses the identification strategy used in this paper in an attempt to make a causal statement about the impact of food prices on political unrest.

\subsection{Identification Strategy}

Food prices cannot be argued to be exogenous to political unrest in equation 1. Therefore, some thought must be given as to how to best make a causal statement about the impact of food prices on political unrest. The identification strategy used in this paper relies on the use of an instrumental variable (IV), i.e., a variable that is correlated with food prices but uncorrelated with the error term in equation 1. Such an IV must thus be able to explain food prices without affecting political unrest except through food prices. 
The variable used to identify the causal relationship between food prices and political unrest in this paper is the number of natural disasters - defined here as drought, episodes of extreme temperature, floods, insect infestations, storms, volcanic eruptions, and wildfires - in a given month. That droughts, episodes of extreme temperature, floods, insect infestations, storms, and wildfires constitute shocks to the supply of food should not be controversial. That volcanic eruptions should be included among the natural disasters used as an IV, however, is not immediately obvious, but Ó Gráda (2009) and Fraser and Rimas (2010) note that episodes of extreme food scarcity often follow volcanic eruptions. ${ }^{11}$

The identifying assumption is thus that natural disasters are uncorrelated with $\epsilon_{2}$ in the equation

$$
y_{t}=\alpha_{2}+\beta_{2 f} \widehat{f}_{t}+\beta_{2 \sigma} \sigma_{t}+\beta_{2 y} y_{t-1}+\beta_{2 m} m_{t}+\beta_{2 \tau} \tau_{t}+\epsilon_{2 t},
$$

where $\widehat{f}_{t}$ is the predicted value of $f_{t}$ obtained from the first-stage regression of food prices on natural disasters and all the exogenous covariates in equation 2 , such that

$$
f_{t}=\alpha_{3}+\beta_{3 n} n_{t}+\beta_{3 \sigma} \sigma_{t}+\beta_{3 y} y_{t-1}+\beta_{3 m} m_{t}+\beta_{3 \tau} \tau_{t}+\epsilon_{3 t},
$$

where $n_{t}$ is the number of natural disasters in period $t, \nu_{t}$ is an error term with mean zero, and all other variables are defined as above. Just as in the case of equation 1, equation 2 is

\footnotetext{
${ }^{11}$ Robustness checks are conducted in section 5 which rely on a progressively narrower definition of natural disaster by excluding in turn volcanic eruptions and wildfires, storms, insect infestations, and episodes of extreme temperature.
} 
estimated twice so as to provide a robustness check on the overall results: once for an index of the overall price of food, and once for an index of the price of cereals.

One may be tempted to use the number of natural disasters in period $t$ as an instrument for food price volatility in addition to instrumenting for the food price level, and thus to run an additional first-stage regression like equation 3 with $\sigma_{t}$ as the dependent variable. But this is an example of what Wooldridge (2002, p.236) refers to as a "forbidden regression," as each endogenous variable requires its own instrument. It is thus because there is only one instrument available in this case that the empirical results on the impact of food price volatility on political unrest cannot be argued to be causal in this paper. ${ }^{12}$

How are natural disasters a good IV for food prices in the context of equations 2 and 3? Within a given month, natural disasters constitute unpredictable shocks to the supply of and demand for food. ${ }^{13}$ Although though the use of rainfall as an IV has recently been questioned due to the predictable nature of rainfall (see the discussion of Miguel et al., 2004 in Sovey and Green, 2011), the natural disasters used in this paper should be unpredictable. Indeed, although some of the natural disasters included in the IV are more likely in certain seasons (e.g., droughts and floods), the presence of month dummies in equations 1 to 2 should greatly reduce, if not altogether eliminate, the predictability of natural disasters. In

\footnotetext{
${ }^{12}$ During preliminary work, the IV was disaggregated into its constituent parts (i.e., droughts, episodes of extreme temperature, floods, insect infestations, storms, volcanic eruptions, and wildfires) in an attempt to establish the causal impacts. Those specifications were discarded because of weak IVs: the Stock-Yogo (2002) null hypothesis of a weak set of IVs could not be rejected in either first-stage equation for both food and cereals.

${ }^{13}$ Although natural disasters are usually conceived of as shocks to the supply of food (see for example Del Ninno et al., 2003), the fact that natural disasters can kill or displace large numbers of people and affect food marketing infrastructure (e.g., roads, bridges, ports, and warehouses) makes them equally likely to also affect the demand for food.
} 
other words, within a given month, the number of natural disasters should be unpredictable. Similarly, the inclusion of a time trend should control for increases in the number of food riots, food prices, food price volatility, and the number of natural disasters simply due to the passage of time. The inclusion of a time trend should thus control for the fact that the number of natural disasters has risen sharply between 1900 and 2010, along with the number of people affected and the estimated value of the damages caused by those same disasters (CRED, 2011).

Even though it is not possible by the very definition of what constitutes a natural disaster for political unrest to cause natural disasters, could a natural disaster occur early in a given month and influence the degree of political unrest later on in the same month through a variable other than food prices? This possibility cannot be ruled out. For example, the World Bank (2010, p.49) notes that disaster relief is often used by those who oversee its distribution as an additional weapon in civil conflicts. For example, Polman (2010) also provides several vivid examples where relief, assistance, and the efforts of nongovernmental organizations were captured by specific groups and used as weapons in civil conflicts. Likewise, the Indonesian government used some of the assistance it received after the tsunami of December 2004 to pacify some of the Free Aceh Movement insurgents, in which case disaster relief was used to foster peace rather than conflict (World Bank, 2010, p.49). Such occurrences, however, are highly unlikely given that the median lag on emergency shipment of relief aid is more than four months (Barrett and Maxwell, 2005).

Likewise, natural disasters could lead to job losses via destroyed capital, which would 
make it easier to recruit disaffected and disenfranchised populations for civil conflict. This cannot be ruled out, but once again, it is unlikely that this can contaminate the empirical results. Indeed, for this to happen, it would need to be the case that a natural disaster directly leads to political unrest in the same region or country as the one in which it takes place, which would in turn require that that region or country is a price maker, i.e., that it has enough market power so as to significantly affect food or cereal prices worldwide. This is in not impossible, but it is highly improbable given the scope of the data, the fact that world markets are well integrated and that only few countries have enough market power to significantly affect the price of food, and the short time frame (i.e., one month) of each observation.

Although it is possible that within a given month, a natural disaster occurs that influences the degree of political unrest within the same month through a variable other than food prices, the dependent variable used in this paper makes this unlikely. Indeed, the dependent variable only measures instances of food-related political unrest, and not of protests, demonstrations, riots, strikes, etc. related to other resources, so the likelihood that $n_{t}$ is correlated with $\epsilon_{2 t}$ should be relatively low. The next section gives a precise definition of the dependent variable as well precise definitions of the variables of interest, the IV, and the control variables, along with a discussion of descriptive statistics. 


\section{Data and Descriptive Statistics}

The data used in this paper come from three sources. The measure of political unrest used as the dependent variable is a proxy for actual food-related political unrest. It comes from a LexisNexis Academic search of all news in English between January 1990 and January 2011 containing at least five occurrences of the terms "cereal," "commodity," "food," "grain," or "staple," and their plural forms and at least five occurrences of the terms "demonstration," "mob," "protest," "riot," "strike," "unrest" or "violence" and their plural forms. The "at least five occurrences" criterion was applied to each component of the search in an effort to weed out news items such as articles about food worker strikes in the hotel industry, for

example. This variable will hereafter be referred to interchangeably as the number of food riots, political unrest, the count of news stories, or the news count.

The number of news sources covered by LexisNexis can vary between time periods as news outlets move in and out of the data base. In this paper, the assumption is that this occurs at random. Alternatively, even if one were to assume that this is a systematic measurement error problem, the identification strategy would account for this. Indeed, in that case, one would observe $y_{t}^{\prime}=y_{t}+\xi_{t}$, in which case equation 1 would become

$$
y_{t}=\alpha_{1}+\beta_{1 f} f_{t}+\beta_{1 \sigma} \sigma_{t}+\beta_{1 y} y_{t-1}+\beta_{1 m} m_{t}+\beta_{1 \tau} \tau_{t}+v_{1 t}
$$

where $v_{1 t}=\epsilon_{1 t}-\xi_{1 t}$, the new error term, has two components (i) the usual error term from equation $1 \epsilon_{1 t}$, and (ii) the measurement error on the dependent variable $\xi_{1 t}$. A systematic 
measurement error problem would then mean that $v_{1 t}$ is correlated with $f_{t}$ on the righthand side of equation 4 , but this is an endogeneity problem similar to the one posed by the fact that political unrest and food prices are jointly determined. As a result, the IV used in an attempt to identify the causal impact of food prices on political unrest overcomes this endogeneity problem also by virtue of making the variation in food prices exogenous to political unrest.

The food prices used as the variables of interest are the FAO's food price index and the FAO's cereal price index. ${ }^{14}$ The FAO's food price index is a monthly indicator of the price of food worldwide that covers five food groups (meat, dairy, cereals, oils and fats, and sugar) representing 55 commodities. To come up with an aggregate food price index, the FAO takes the average of the five food groups and weights them using group-specific export shares for the period 2002-2004. The size of the sample used for analysis in this paper - 253 monthly observations from January 1990 to January 2011 inclusively - was ultimately determined by the fact that the FAO only started recording food prices in January 1990.

The natural disaster data used to construct the IV come from the Center for Research on the Epidemiology of Disasters' (CRED) EM-DAT database, which was used by Strömberg (2007) to study the relationship between natural disasters and economic development. The disasters retained for analysis in this paper are those that are thought to constitute shocks to the supply of and demand for food: droughts, episodes of extreme temperature, floods,

\footnotetext{
${ }^{14}$ The indices used in this paper are deflated (i.e., real) measures. Robustness checks conducted with nominal food price indices during preliminary work leave the qualitative results unchanged. Those are not shown for brevity, but they are available from the author upon request.
} 
insect infestations, storms, volcanic eruptions, and wildfires. Disasters such as earthquakes, mass movements, epidemics, and animal stampedes, however, were not retained. A natural disaster is included in the EM-DAT database only if it satisfies at least one of the following criteria: $:^{15}$

1. At least ten persons are killed,

2. At least 100 persons require immediate assistance, are displaced, or evacuated,

3. A state of emergency is declared by public officials, or

4. Public officials call for international assistance.

In the empirical, a natural disaster is recorded in the month when it began. A disaster that unfolded in the current month but which began in an earlier month is thus not recorded as having occurred in the current month. For example, an episode of extreme temperature that begins on April 15 and ends on July 13 is only recorded as having occurred in April. Natural disasters whose beginning month was coded as "00" (i.e., unknown) in the EM-DAT database were simply dropped from the data because it was impossible to ascribe them to a specific month. This assumes that these "month-00" disasters occur at random.

Turning to the descriptive statistics in table 1, the average month sees about 69 mentions of food-related political unrest in the English-language media. This figure masks a considerable amount of heterogeneity, however, as the number of such mentions ranges from two in February 1990 to 473 in April 2008. Likewise, the food price index was equal to roughly 113

\footnotetext{
${ }^{15}$ More information on the EM-DAT data can be obtained from http://www.emdat.be/explanatory-notes.
} 
on average, with a minimum of 83 in July 1999 and a maximum of 203.3 in January 2011. The cereal price index averaged about 112 between January 1990 and January 2011. The cereals price index, however, was markedly more volatile than the food price index, both in terms of the standard deviation and of the average three-month volatility for each price series. Indeed, the three-month standard deviation of the cereals price index is equal to 3.1 on average, whereas the three-month standard deviation of the food price index is equal to 2.2 on average. Six-month volatility exhibits a similar pattern.

Natural disasters most often take the form of floods and storms, with a monthly average of 11 floods and eight storms. At the other end of the natural disaster spectrum, insect infestations, volcanic eruptions, and wildfires occur on average less than once a month, with 0.11 insect infestations, 0.47 volcanic eruptions, and 0.99 wildfires per month. The average month sees about 23 occurrences of natural disasters.

\section{Estimation Results}

Before presenting and discussing estimation results for various specifications of equations 1 and 2, it is instructive to start by looking at some nonparametric evidence so as to check whether food prices and political unrest appear correlated at all. In that spirit, figure 1 plots time series for the food price level, the three-month volatility of the food price level, and for the count of news stories about food riots between January 1990 and January 2011.

Figure 1 indicates that spikes in the food price level are often accompanied by a spike in 
the count of news stories. Spikes in food price volatility, however, seem to follow spikes in food prices. Although this is true by construction - food price volatility is defined here as the standard deviation of the food price level time series over the preceding three months, and so a food price spike in a given period should increase food price volatility in the same period, everything else equal - this already casts some doubt on the hypothesis that food price volatility causes political unrest.

Turning to the parametric evidence, the coefficient of correlation between the food price level and the count of news stories is equal to 0.61 and is significant at the 1 percent level. Likewise, the coefficient of correlation between food price volatility and the count of news stories is equal to 0.30 , and it is also significant at the 1 percent level. Similarly, the coefficient of correlation between the cereal price level and the count of news stories is equal to 0.60 , the coefficient of correlation between cereal price volatility and the count of news stories is equal to 0.26. Both are significant at the 1 percent level.

Obviously, figure 1 and the correlation coefficients just discussed fail to control for confounding factors. The results in table 2 a control for such confounding factors by including controls for the count of news stories in the previous month, a time trend, and a set of monthly dummy variables. The results in table $2 \mathrm{a}$ show that once those covariates are included, the food price level and the cereal price level are both positively associated with political unrest. Moreover, it appears that food price volatility is negatively correlated with political unrest. 
As was discussed in section 3, Durbin-Watson tests indicate that the error term in the first two columns of table 2 are not serially correlated. For column 1, the test statistic was equal to 2.00. Given the lower and upper critical values of the test, which were respectively equal to 1.67 and 1.92 , this constitutes evidence that the error term is not serially correlated. For column 2, the test statistic was equal to 1.96 , which similarly constitutes evidence that the error term is not serially correlated, and thus that Newey-West standard errors are not necessary. Moreover, when conducting Dickey-Fuller (DF) tests, one rejects the null hypothesis of a unit root in the dependent variable (with a DF test statistic of -5.99 , since this is below the 1 percent critical value of -3.46 ), food and cereal price volatility (with DF test statistics of -4.87 and -6.22 ), and the instrumental variable (with a DF test statistic of -9.51), but one cannot reject the null for the food and cereal price levels (with DF test statistics of 2.19 and 0.42 , since this is above the 1 percent critical value of -3.46 ). As was mentioned above, however, Wang and Tomek (2007) find that structural breaks in food prices account for their apparent nonstationarity. For this reason, and to make the interpretation of empirical results more straightforward, all the variables in this paper are expressed in levels.

Table 2a presents interesting correlations between food prices and political unrest, but those correlations are just that, and in no way do they imply that food prices actually cause political unrest. Table $2 \mathrm{~b}$ attempts to make a causal statement about the impact of the food price level on political unrest by presenting estimation results in which natural disasters are used to instrument the food price level. First-stage instrumenting regressions for food prices 
are presented for these results, but they are omitted from the remainder of the empirical results both for brevity and because they are similar throughout. That is, the number of natural disasters in a given month depresses food prices in the same month. This may come as a surprise to some, but recall that natural disasters can affect the supply of and the demand for food. The fact that natural disasters depress the price of food suggests that natural disasters tend to matter most in regions and countries that produce a negligible amount of food. In such places, the effects of decreased demand for food on the part of large segments of the population affected by natural disasters appear to offset the effects of a decrease in the supply of food.

But what matters here is neither the sign nor the magnitude of the impact of natural disasters on food prices but its significance. In both cases, the IV is statistically significant at less than the 1 percent level. In fact, in both columns 1 and 3 , the $F$-statistic on the IV exceeds the threshold of 10 set by Stock and Yogo (2002) for an IV not to be considered weak, which is also true of all of the IV estimation results in this paper. In addition - and following Angrist and Pischke (2008) and Chernozhukov and Hansen (2008), who recommend running a diagnostic regression of the dependent variable on the IV is good practice - table A1 presents the results of a reduced-form regression of political unrest on the number of natural disasters in a given month. That the reduced-form relationship between the IV and the dependent variable is significant at the 1 percent level is evidence in favor of a causal relationship flowing from natural disasters to political unrest.

The second-stage results in columns 2 and 4 of table $2 \mathrm{~b}$ indicate that accounting for the 
endogeneity of food prices relative to political unrest entails a more than twofold increase in the estimated impact of food prices on political unrest. Thus, although the estimated coefficients for the food price level and for food price volatility in the naïve specifications of table 2a have the right sign and significance relative to the same estimated coefficients in columns 2 and 4 of table $2 \mathrm{~b}$, they understate the role of food prices as a determinant of political unrest. Furthermore, the results in columns 2 and 4 of table $2 \mathrm{~b}$ show that even when attempting to make a causal statement about the impact of the food price level on political unrest, the negative relationship between food price volatility and political unrest remains.

Although it is impossible to make a causal statement about the impact of food price volatility on political unrest in the context of this paper, this is in line with empirical results in the applied microeconomics literature. Indeed, Bellemare et al. (2011) find holding food price levels constant, the negative effects of food price volatility are largely felt by food producers who, by virtue of having to dedicate resources to food production long before the resolution of price uncertainty, cannot make profit-maximizing production decisions in the presence of food price volatility. Food consumers, however, can always adjust their food consumption bundle after the resolution of price uncertainty, and so for them, greater food price volatility (holding the food price level constant once again) means an increased likelihood of enjoying price discounts on food. Since it is food consumers - who are concentrated in urban areas, and who represent a large percentage of the population and most countries - rather than food producers - who are spread out over large rural areas, and who represent a small percentage 
of the population in most countries - who drive political unrest according to the historical literature on food riots discussed in section 2, the sign and significance of the estimated coefficient on food price volatility are not surprising.

The results in tables $2 \mathrm{a}$ and $2 \mathrm{~b}$ indicate also that the reporting of political unrest has been increasing over time, given the sign and significance of the linear time trend, and that the number of news stories about food riots in a given month is correlated with the number of news stories about food riots the previous month. This suggests that political unrest tends to carry over from month to month, but decreasingly so given that the estimated coefficient on the count of news stories in the previous month is less than one.

To make sure that political unrest in the current month is not significantly affected by political unrest in the months before the previous month, table 3 re-estimates the IV specifications in columns 3 and 4 of table 2 by including the count of news stories in $t-2$ and in $t-3$ as explanatory variables. The estimated coefficients for these two variables are not significant in either specification, and the estimated coefficients for the food price levels and food price volatilities are practically unaffected by the inclusion of these two variables. This contrasts with the findings in Besley and Burgess (2002), which imply that Indian state governments are more likely to respond to crop flood damage with humanitarian assistance when there is greater media coverage of the floods in India. In the context of this paper, greater media coverage in $t-1, t-2$, and $t-3$ need be associated with a decrease in political unrest in $t$ (via improvements in food prices as a result of public food distribution) given that the data set covers several countries. This could be because the countries in which the 
media covers political unrest in $t-1, t-2$, and $t-3$ are not necessarily the same as the countries in which there is political unrest in $t$.

The specification in table 4 consider whether the results in table $2 \mathrm{~b}$ are driven by the food crises of 2008 and 2010-2011. The results in columns 1 and 2 thus include a dummy variable equal to one if the year is 2008 and equal to zero otherwise. Likewise, the results in columns 3 and 4 include a dummy variable equal to one if the year is 2010 or 2011 and equal to zero otherwise. While the dummy for 2008 is positive and significant in the specification focusing on food prices (column 1), which indicates that there has indeed been more foodrelated political unrest in 2008 than in the other years considered in this paper, it is not significant in the specification focusing on cereal prices (column 2). On average the dummy for 2010-2011 is not significantly different from zero. More importantly, the magnitude of the estimated coefficients for the food price levels remain once again unchanged. The magnitude of the estimated coefficients for the food price volatilities, however, increase slightly when controlling for the food crisis of 2008 relative to the results in table $2 \mathrm{~b}$, which suggests that the magnitude of the association between food price volatility and political unrest was actually weaker in 2008 than at other times.

Could the inclusion of food price volatility drive the result according to which food price levels appear to cause political unrest? The estimation results in table 5 answer that question in the negative by showing that the estimated coefficient for the food price levels are still significant when food price volatility is omitted, in both the OLS and IV specifications. 
Similarly, could excluding food price levels to only include food price volatility as a variable of interest explain the reasoning of some commentators, who have claimed that food price volatility causes political unrest? It cannot, as the estimated coefficients on both food and cereal price volatility in columns 1 and 2 of table 6 are not statistically different from zero at any of the conventional levels when the food and cereal price levels are omitted from their respective specification.

Finally, the appendix presents estimation results for several robustness checks. As regards the IV, to make sure that the results in this paper are robust to alternative definitions of "natural disasters," and to make sure that the results are robust to the way various natural disasters can affect food prices, the results in table A2 progressively exclude specific types of natural disasters from the IV. In column 1, volcanic eruptions and wildfires are eliminated given that they appear to be the least likely to affect food prices. Columns 2 to 4 progressively remove storms, insect infestations, and episodes of extreme temperature from the IV. The empirical results are stable across all these alternative definitions, for both food and cereal prices.

Following Angrist and Pischke (2008) once again, the specifications in table A3 test whether political unrest Granger-causes food prices by including three food price lags as well as three food price leads. The null hypothesis of no Granger causation flowing from political unrest to food prices is such that the estimated coefficients for the food prices in $t+1, t+2$, and $t+3$ are not significant, save for the second food price lead. This could mean that political unrest Granger-causes food prices, but this appears unlikely given that 
the coefficient on the second food price lead is only significant at the 9.9 percent level and that all three food price leads are not jointly significant. This is strengthened by the results in the second column of table A3, which show that political unrest does not Granger-cause cereal prices.

Finally, the specifications in table A4 take a longer view of price volatility by considering six- instead of three-month food and cereal price volatility. In this case, although the relationship between food price volatility and political unrest is no longer statistically significant, the relationship between food price levels and political unrest is still statistically significant and positive, and of comparable magnitude. In other words, if food price volatility exerts an impact on political unrest, it appears that it is short-term (i.e., three-month) and not longer-term (i.e., six-month) price volatility that matters, and it appears that the relationship between political unrest and food price volatility, instead of being positive as is so commonly asserted by public commentators, is seemingly negative.

These results thus suggest that whether one considers the food price index or the cereals price index, there appears to be a robust causal relationship flowing from the food price level to political unrest, proxied here by the number of news stories about food riots. Likewise, the results suggest that food price volatility - often depicted in the media and by policy makers as the main culprit in causing political unrest - is, if anything, negatively correlated with political unrest, although this relationship cannot be argued to be causal. Put simply, rising food prices appear to cause food riots, and the debate surrounding food prices should be recentered on rising food prices rather than focus on food price volatility. 


\section{Conclusion}

Do food prices cause political unrest? The results in this paper indicate that the answer to this question is a qualified "yes." While rising food prices appear to cause food riots, food price volatility is negatively associated with political unrest. These findings go against much of the prevailing rhetoric surrounding food prices. Indeed, whereas many in the media and among policy makers were quick to blame food price volatility for the food riots of 2008 and of 2010-2011, the empirical results in this paper indicate that rising food price levels are to blame and that increases in food price volatility may actually decrease the number of food riots. Moreover, specifications that focus on food price volatility at the expense of food price levels show that the latter is not statistically significantly related to the former. These findings are in line with those in the applied microeconomics literature on the impacts of rising food prices (Deaton, 1989) and of food price volatility (Bellemare et al., 2011).

What are the implications of these findings for policy? First, policy makers should focus on rising food prices, which appear to cause political unrest, rather than on food price volatility, which is actually associated with decreases in political unrest. All of the time and resources that have so far been dedicated to food price volatility would have been better spent on addressing rising food prices. In the future, this means that policies aimed at increasing the supply of food will be the most helpful, whether this means investing in agricultural research aimed at increasing agricultural yields (Dorward et al., 2004), encouraging urban or peri-urban agriculture (Maxwell, 1995), liberalizing the international trade

of agricultural commodities, increasing access to and the use of biotechnology in developing 
countries (Paarlberg, 2009), eliminating farm subsidies in industrialized countries, and so on.

Second, although it may be tempting to do away with consumer food price subsidies in the current context of budget austerity, policy makers should be very cautious when trying to eliminate such subsidies. Indeed, in many developing countries, local political economy considerations introduce a systematic bias in favor of urban households when it comes to food policy, which pushes governments to subsidize the price of food in an effort to keep urban discontent at bay (Lipton, 1977; Bates, 1981). Given that food riots almost always occur in urban areas, however, abandoning these food price subsidies may be ill-advised, especially since these policies often appear to have been put in place to avoid food riots in the first place. In such cases, a better policy may be one that progressively abandons food price subsidies. This is especially so given that it is likely that individuals exhibit loss aversion over food prices (Timmer, 2010), i.e., for equal-valued increases and decreases in food prices, the welfare losses caused by price increases are larger in magnitude than the welfare gains caused by price decreases.

Although food prices are determined on international markets by forces beyond the control of national governments, policy responses to rising food prices are within the hands of national governments and should respond to local contexts. What type of policy is bestsuited to each of those contexts will have to rely on analyses conducted at a more micro level. For now, this type of analysis is left for future research. 


\section{References}

[1] Angrist, Joshua D. and Jörn-Steffen Pischke (2008), Mostly Harmless Econometrics, Princeton: Princeton University Press.

[2] Arezki, Rabah and Markus Brückner (2011), "Food Prices and Political Instability," Working Paper, International Monetary Fund.

[3] Arnold, David (1979), "Dacoity and Rural Crime in Madras, 1860-1940," Journal of Peasant Studies 6(2): 140-167.

[4] Auyero, Javier and Thomas P. Moran (2007), "The Dynamics of Collective Violence: Dissecting Food Riots in Contemporary Argentina," Social Forces 85(3): 1341-1367.

[5] Barrett, Christopher B. (1996), "On Price Risk and the Inverse Farm Size-Productivity Relationship," Journal of Development Economics 51(2): 193-215.

[6] Barrett, Christopher B. and Daniel G. Maxwell (2005), Food Aid After Fifty Years, London: Routledge.

[7] Bates, Robert H. (1981), Markets and States in Tropical Africa, Berkeley: University of California Press.

[8] Bellemare, Marc F., Christopher B. Barrett and David R. Just (2011), "The Welfare Impacts of Commodity Price Volatility: Evidence from Rural Ethiopia," Working Paper, Duke University. 
[9] Besley, Timothy, and Robin Burgess (2002), "The Political Economy of Government Responsiveness: Theory and Evidence from India," Quarterly Journal of Economics 117(4): 1415-1451.

[10] Bohlken, Anjali Thomas and Ernest J. Sergenti (2010), "Economic Growth and Ethnic Violence: An Empirical Investigation of Hindu-Muslim Riots in India," Journal of Peace Research 47(5): 589-600.

[11] Bush, Ray (2010), "Food Riots: Poverty, Power, and Protest," Journal of Agrarian Change 10(1): 119-129.

[12] Chernozhukov, Victor and Christian Hansen (2008), "The Reduced Form: A Simple Approach to Inference with Weak Instruments," Economics Letters 100(1): 68-71.

[13] Ciezadlo, Annia (2011), "Let Them Eat Bread," in The New Arab Revolt: What Happened, What It Means, and What Comes Next, New York: Council on Foreign Relations, also available at http://www.foreignaffairs.com/articles/67672/ annia-ciezadlo/let-them-eat-bread, last accessed June 9, 2011.

[14] Clapp, Jennifer (2009), "Food Price Volatility and Vulnerability in the Global South: Considering the Global Economic Context," Third World Quarterly 30(6): 1183-1196.

[15] Clark, Peter (1976), "Popular Protest and Disturbances in Kent," Economic History Review 29(3): 365-381. 
[16] CRED (2011), "Natural Disaster Trends," http://www. emdat.be/ natural-disasters-trends last accessed July 12, 2011.

[17] Deaton, Angus (1989), "Household Survey Data and Pricing Policies in Developing Countries," World Bank Economic Review 3(2): 183-210.

[18] Del Ninno, Carlo, Paul A. Dorosh and Lisa C. Smith (2003), "Public Policy, Markets and Household Coping Strategies in Bangladesh: Avoiding a Food Security Crisis Following the 1998 Floods," World Development 31(7): 1221-1238.

[19] DiPasquale, Denise, and Edward L. Glaeser (1998), "The Los Angeles Riot and the Economics of Urban Unrest," Journal of Urban Economics 43(1): 52-78.

[20] Dorward, Andrew, Jonathan Kydd, Jamie Morrison and Ian Urey (2004), "A Policy Agenda for Pro-Poor Agricultural Growth," World Development 32(1): 73-89.

[21] Fraser, Evan D.G. and Andrew Rimas (2010), Empires of Food, New York: Free Press.

[22] Gilbert, Christopher L. and C. Wyn Morgan (2010), "Food Price Volatility," Philosophical Transactions of the Royal Society B 365(1554): 3023-3034.

[23] Goldstone, Jack A. (1982), "The Comparative and Historical Study of Revolutions," Annual Review of Sociology 8: 187-207.

[24] Haddad, Lawrence, Marie T. Ruel and James L. Garrett (1999), "Are Urban Poverty and Undernutrition Growing? Some Newly Assembled Evidence," World Development 27(11): 1891-1904. 
[25] Jacks, David S., Kevin H. O'Rourke and Jeffrey G. Williamson (2011), "Commodity Price Volatility and World Market Integration since 1700," Review of Economics and Statistics forthcoming.

[26] Kharas, Homi (2011), "Making Sense of Food Price Volatility," http://www. brookings.edu/opinions/2011/0303_food_prices_kharas.aspx last accessed July 11, 2011.

[27] Lobell, David B., Wolfram Schlenker and Justin Costa-Roberts (2011), "Climate Trends and Global Crop Production Since 1980," Science forthcoming.

[28] Maxwell, Daniel G. (1995), "Alternative Food Security Strategy: A Household Analysis of Urban Agriculture in Kampala," World Development 23(10): 1669-1681.

[29] Miguel, Edward, Shanker Satyanath and Ernest Sergenti (2004), "Economic Shocks and Civil Conflict: An Instrumental Variables Approach," Journal of Political Economy 112(4): 725-753.

[30] Ó Gráda, Cormac (2009), Famine: A Short History, Princeton: Princeton University Press.

[31] Naylor, Rosamond L. and Walter P. Falcon (2010), "Food Security in an Era of Economic Volatility," Population and Development Review 36(4): 693-723.

[32] Paarlberg, Robert (2009), Starved for Science: How Biotechnology Is Being Kept Out of Africa, Cambridge: Harvard University Press. 
[33] Polman, Linda (2010), The Crisis Caravan: What's Wrong with Humanitarian Aid, New York: Metropolitan Books.

[34] Reuters (2011), "Comments from Sarkozy G-20 News Conference," http://www. reuters.com/article/2011/01/24/us-g20-highlights-idUSTRE70N1SB20110124 last accessed June 9, 2011.

[35] Rudé, George (1964), The Crowd in History, New York: Wiley.

[36] Schneider, Mindi (2008), “We Are Hungry!' - A Summary Report of Food Riots, Government Responses, and States of Democracy in 2008," Working Paper, Cornell University.

[37] Sovey, Allison J. and Donald P. Green (2011), "Instrumental Variables Estimation in Political Science: A Readers' Guide," American Journal of Political Science 55(1): 188200.

[38] Smith, Andrew F. (2011), Starving the South, New York: St. Martin's Press.

[39] Stock, James H. and Motohiro Yogo (2002), "Testing for Weak Instruments in Linear IV Regression," Working Paper, National Bureau of Economic Research.

[40] Strömberg, David (2007), "Natural Disasters, Economic Development, and Humanitarian Aid," Journal of Economic Perspectives 21(3): 199-222.

[41] Taylor, Lynne (1996), "Food Riots Revisited," Journal of Social History 30(2): 483-496. 
[42] Tilly, Louise A. (1971), "The Food Riot as a Form of Political Conflict in France," Journal of Interdisciplinary History 2(1): 23-57.

[43] Timmer, C. Peter (2010), "Behavioral Dimensions of Food Security," Proceedings of the National Academy of Science forthcoming.

[44] Wade, Rex A. (2005), The Russian Revolution, 1917, Cambridge: Cambridge University Press.

[45] Walton, John and David Seddon (1994), Free Markets and Food Riots, Oxford: Blackwell.

[46] Wang, Dabin, and William G. Tomek (2007), "Commodity Prices and Unit Root Tests," American Journal of Agricultural Economics 89(4): 873-889.

[47] Webb, Patrick (2010), "Medium- to Long-Run Implications of High Food Prices for Global Nutrition," Journal of Nutrition 140(1): 143S-147S.

[48] Wilkinson, Steven I. (2009), "Riots," Annual Review of Political Science 12: 329-343.

[49] World Bank (2010), Natural Hazards, Unnatural Disasters: The Economics of Effective Prevention, Washington: The World Bank. 


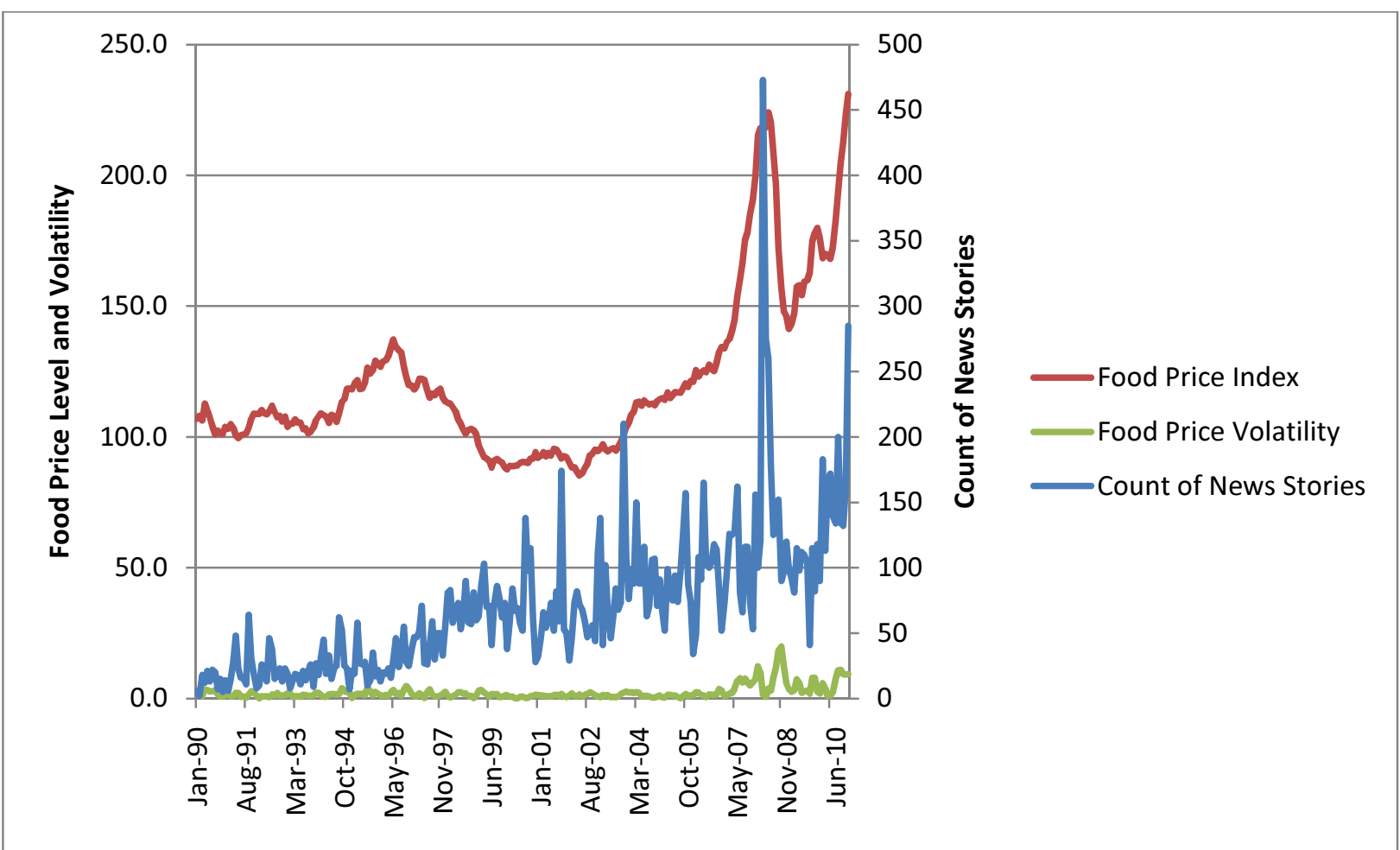

Figure 1. Food Price Index, Three-Month Food Price Volatility, and Political Unrest, January 1990 to January 2011. 
Table 1. Descriptive Statistics, January 1990 to January 2011

\begin{tabular}{lrrr}
\hline Variable & Mean & (Std. Dev.) & Observations \\
\hline $\begin{array}{l}\text { Dependent Variable } \\
\quad \text { Count of News Stories }\end{array}$ & 69.29 & $(55.09)$ & \\
Food Prices & & & 253 \\
$\quad$ Food Price Index & 112.68 & $(21.96)$ & 253 \\
Cereals Price Index & 111.88 & $(30.44)$ & 253 \\
Food Price Three-Month Volatility & 2.23 & $(2.25)$ & 251 \\
Food Price Six-Month Volatility & 3.63 & $(3.70)$ & 251 \\
Cereals Price Three-Month Volatility & 3.06 & $(3.23)$ & 248 \\
Cereals Price Six-Month Volatility & 5.22 & $(5.08)$ & 248 \\
Natural Disasters & & & \\
Drought & 1.15 & $(1.27)$ & 253 \\
Extreme Temperature & 1.34 & $(2.34)$ & 253 \\
Floods & 10.97 & $(6.06)$ & 253 \\
Insect Infestations & 0.11 & $(0.57)$ & 253 \\
Storms & 8.06 & $(4.74)$ & 253 \\
Volcanic Eruptions & 0.47 & $(0.70)$ & 253 \\
Wildfires & 0.99 & $(1.34)$ & 253 \\
Count of Natural Disasters & 23.09 & $(9.45)$ & 253 \\
\hline
\end{tabular}

Note: All price figures are in real terms. 
Table 2a. OLS Estimation Results for the Determinants of Political Unrest, 1990-2011.

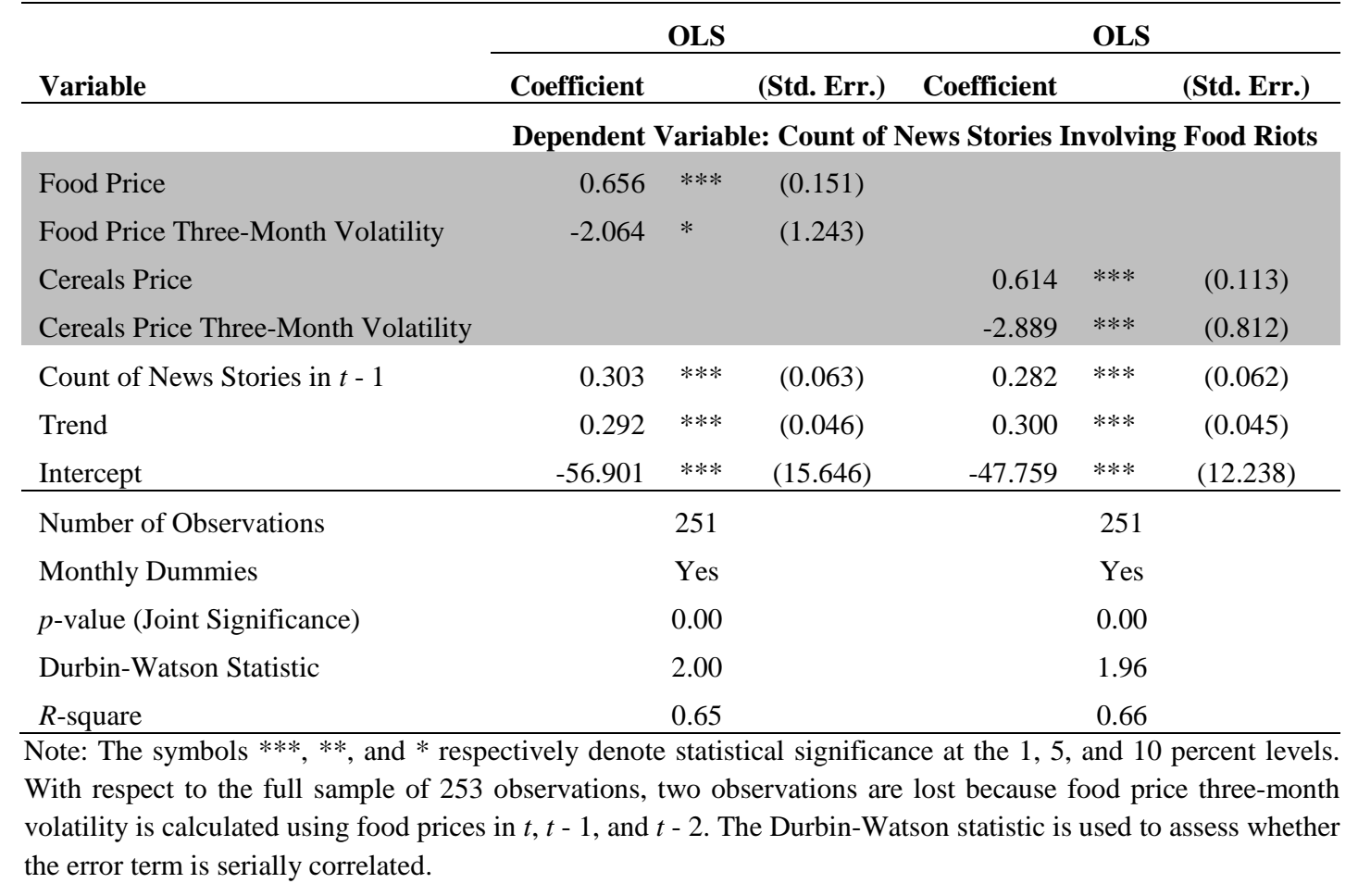


Table 2b. IV Estimation Results for the Determinants of Political Unrest, 1990-2011.

\begin{tabular}{|c|c|c|c|c|c|c|c|c|c|c|c|c|}
\hline \multirow[b]{2}{*}{ Variable } & \multicolumn{3}{|c|}{$\begin{array}{c}\text { (1) } \\
\text { First Stage: } \\
\text { Food Price }\end{array}$} & $\begin{array}{r}\text { Secc } \\
\text { Count o } \\
\end{array}$ & $\begin{array}{l}(2) \\
\text { nd St } \\
\text { New: }\end{array}$ & $\begin{array}{l}\text { e: } \\
\text { ttories }\end{array}$ & $\begin{array}{l}\text { Fir } \\
\text { CeI } \\
\end{array}$ & $\begin{array}{l}(3) \\
\text { st Stag } \\
\text { eal Pr }\end{array}$ & & $\begin{array}{r}\text { Seco } \\
\text { Count o } \\
\end{array}$ & $\begin{array}{l}(4) \\
\text { nd St } \\
\text { New }\end{array}$ & $\begin{array}{l}\text { e: } \\
\text { tories } \\
\end{array}$ \\
\hline & Coefficient & & $\begin{array}{l}\text { (Std. } \\
\text { Err.) }\end{array}$ & Coefficient & & $\begin{array}{l}\text { (Std. } \\
\text { Err.) }\end{array}$ & Coefficient & & $\begin{array}{l}\text { (Std. } \\
\text { Err.) } \\
\end{array}$ & Coefficient & & $\begin{array}{l}\text { (Std. } \\
\text { Err.) } \\
\end{array}$ \\
\hline Food Price & & & & 1.305 & $*$ & $(0.520)$ & & & & & & \\
\hline Food Price Three-Month Volatility & 3.977 & $* * *$ & $(0.444)$ & -4.965 & $*$ & $(2.564)$ & & & & & & \\
\hline Cereals Price & & & & & & & & & & 0.905 & $* * *$ & $(0.324)$ \\
\hline Cereals Price Three-Month Volatility & & & & & & & 4.234 & $* * *$ & $(0.346)$ & -4.200 & $* * *$ & $(1.595)$ \\
\hline Count of News Stories in $t-1$ & 0.119 & $* * *$ & $(0.025)$ & 0.222 & $* *$ & $(0.090)$ & 0.163 & $* * *$ & $(0.032)$ & 0.231 & $* * *$ & $(0.082)$ \\
\hline Trend & 0.116 & $* * *$ & $(0.021)$ & 0.249 & $* * *$ & $(0.058)$ & 0.147 & $* * *$ & $(0.027)$ & 0.278 & $* * *$ & $(0.051)$ \\
\hline Count of Natural Disasters & -0.638 & $* * *$ & $(0.132)$ & & & & -0.964 & $* * *$ & $(0.166)$ & & & \\
\hline Intercept & 100.122 & $* * *$ & $(4.330)$ & -113.781 & $*$ & $(46.381)$ & 98.782 & $* * *$ & $(5.462)$ & -71.122 & $* * *$ & $(27.321)$ \\
\hline Number of Observations & & & & & & & & & & 51 & & \\
\hline Monthly Dummies & & & & & & & & & & es & & \\
\hline$p$-value (Joint Significance) & & & & & & & & & & 00 & & \\
\hline$F$-statistic (Instrument) & & & & & & & & & & .52 & & \\
\hline$R$-square & & & & & & & & & & 65 & & \\
\hline
\end{tabular}


Table 3. IV Estimation Results for Robustness Checks on the Determinants of Political Unrest Using Quarterly News, $1990-2011$.

\begin{tabular}{|c|c|c|c|c|c|c|}
\hline \multirow[b]{2}{*}{ Variable } & \multicolumn{3}{|c|}{ IV } & \multicolumn{3}{|c|}{ IV } \\
\hline & Coefficient & & (Std. Err.) & Coefficient & & (Std. Err.) \\
\hline \multicolumn{7}{|c|}{ Dependent Variable: Count of News Stories Involving Food Riots } \\
\hline Food Price & 1.283 & $* *$ & $(0.523)$ & & & \\
\hline Food Price Three-Month Volatility & -5.012 & $* *$ & $(2.529)$ & & & \\
\hline Cereals Price & & & & 0.890 & $* * *$ & $(0.331)$ \\
\hline Cereals Price Three-Month Volatility & & & & -4.182 & $* * *$ & $(1.602)$ \\
\hline Count of News Stories in $t-1$ & 0.201 & $* *$ & $(0.086)$ & 0.214 & $* * *$ & $(0.079)$ \\
\hline Count of News Stories in $t-2$ & 0.042 & & $(0.076)$ & 0.034 & & $(0.074)$ \\
\hline Count of News Stories in $t-3$ & 0.038 & & $(0.069)$ & 0.036 & & $(0.067)$ \\
\hline Trend & 0.221 & $* * *$ & $(0.060)$ & 0.254 & $* * *$ & $(0.054)$ \\
\hline Intercept & -111.777 & $* *$ & $(46.700)$ & -70.003 & $* *$ & $(27.893)$ \\
\hline Number of Observations & & 250 & & & 250 & \\
\hline Monthly Dummies & & Yes & & & Yes & \\
\hline$p$-value (Joint Significance) & & 0.00 & & & 0.00 & \\
\hline$F$-statistic (Instrument) & & 23.43 & & & 33.18 & \\
\hline$R$-square & & 0.63 & & & 0.66 & \\
\hline
\end{tabular}


Table 4. IV Estimation Results for Robustness Checks on the Determinants of Political Unrest Controlling for Food Crises, $1990-2011$.

\begin{tabular}{|c|c|c|c|c|c|c|c|c|c|c|c|c|}
\hline \multirow[t]{2}{*}{ Variable } & \multicolumn{2}{|l|}{ Coefficient } & (Std. Err.) & \multicolumn{2}{|l|}{ Coefficient } & (Std. Err.) & Coefficient & & (Std. Err.) & \multicolumn{2}{|l|}{ Coefficient } & \multirow[t]{2}{*}{ (Std. Err.) } \\
\hline & & & & Dependent $V$ & ariable & : Count of $N$ & ews Stories Ir & Ivolvin & Food Riots & & & \\
\hline Food Price & 1.314 & $* *$ & $(0.512)$ & & & & 1.422 & $* *$ & $(0.651)$ & & & \\
\hline Food Price Three-Month Volatility & -6.241 & $* * *$ & $(2.254)$ & & & & -5.221 & $*$ & $(2.838)$ & & & \\
\hline Cereals Price & & & & 0.881 & $* * *$ & $(0.331)$ & & & & 0.827 & $* *$ & $(0.339)$ \\
\hline Cereals Price Three-Month Volatility & & & & -4.846 & $* * *$ & $(1.358)$ & & & & -3.960 & $* *$ & $(1.628)$ \\
\hline Count of News Stories in $t-1$ & 0.155 & $* *$ & $(0.081)$ & 0.1752798 & $* *$ & $(0.072)$ & 0.212 & $* *$ & $(0.099)$ & 0.241 & $* * *$ & $(0.083)$ \\
\hline Trend & 0.271 & $* * *$ & $(0.062)$ & 0.301 & $* * *$ & $(0.056)$ & 0.252 & $* * *$ & $(0.057)$ & 0.274 & $* * *$ & $(0.050)$ \\
\hline 2008 Dummy & 30.847 & $* *$ & $(15.907)$ & 28.794 & & $(17.842)$ & & & & & & \\
\hline 2010-2011 Dummy & & & & & & & -13.913 & & $(19.317)$ & 12.648 & & $(11.066)$ \\
\hline Intercept & -112.232 & $* *$ & $(46.435)$ & -67.297 & $* *$ & $(28.634)$ & -125.066 & $* *$ & $(58.891)$ & -64.061 & $* *$ & $(28.718)$ \\
\hline Number of Observations & & 251 & & & 251 & & & 251 & & & 251 & \\
\hline Monthly Dummies & & Yes & & & Yes & & & Yes & & & Yes & \\
\hline$p$-value (Joint Significance) & & 0.00 & & & 0.00 & & & 0.00 & & & 0.00 & \\
\hline$F$-statistic (Instrument) & & 24.90 & & & 36.12 & & & 16.89 & & & 30.14 & \\
\hline$R$-square & 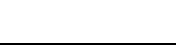 & 0.63 & 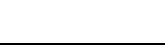 & & 0.66 & 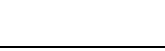 & & 0.61 & & & 0.66 & \\
\hline
\end{tabular}


Table 5. OLS and IV Estimation Results for Robustness Checks on the Determinants of Political Unrest Omitting Price Volatility, 19902011.

\begin{tabular}{|c|c|c|c|c|c|c|c|c|c|c|c|c|}
\hline \multirow[b]{2}{*}{ Variable } & \multicolumn{3}{|c|}{ OLS } & \multicolumn{3}{|c|}{ OLS } & \multicolumn{3}{|c|}{ IV } & \multicolumn{3}{|c|}{ IV } \\
\hline & Coefficient & & $\begin{array}{l}\text { (Std. } \\
\text { Err.) }\end{array}$ & Coefficient & & $\begin{array}{l}\text { (Std. } \\
\text { Err.) }\end{array}$ & Coefficient & & $\begin{array}{l}\text { (Std. } \\
\text { Err.) }\end{array}$ & Coefficient & & $\begin{array}{l}\text { (Std. } \\
\text { Err.) }\end{array}$ \\
\hline & \multicolumn{12}{|c|}{ Dependent Variable: Count of News Stories Involving Food Riots } \\
\hline Food Price & 0.521 & $* * *$ & $(0.127)$ & & & & 0.951 & $* *$ & $(0.385)$ & & & \\
\hline Cereals Price & & & & 0.363 & $* * *$ & $(0.090)$ & & & & 0.687 & $* *$ & $(0.279)$ \\
\hline Count of News Stories in $t-1$ & 0.317 & $* * *$ & $(0.063)$ & 0.316 & $* * *$ & $(0.063)$ & 0.258 & $* * *$ & $(0.081)$ & 0.253 & $* * *$ & $(0.083)$ \\
\hline Trend & 0.285 & $* * *$ & $(0.046)$ & 0.292 & $* * *$ & $(0.045)$ & 0.237 & $* * *$ & $(0.062)$ & 0.246 & $* * *$ & $(0.059)$ \\
\hline Intercept & -46.598 & $* * *$ & $(14.378)$ & -29.621 & $* * *$ & $(11.373)$ & -86.449 & $* *$ & $(36.623)$ & -57.442 & $* *$ & $(25.465)$ \\
\hline Number of Observations & & 252 & & & 252 & & & 252 & & & 252 & \\
\hline Monthly Dummies & & Yes & & & Yes & & & Yes & & & Yes & \\
\hline$p$-value (Joint Significance) & & 0.00 & & & 0.00 & & & 0.00 & & & 0.00 & \\
\hline$F$-statistic (Instrument) & & - & & & - & & & 30.36 & & & 29.05 & \\
\hline$R$-square & & 0.65 & & & 0.65 & & & 0.63 & & & 0.63 & \\
\hline
\end{tabular}


Table 6. OLS Estimation Results for Robustness Checks on the Determinants of Political Unrest Omitting Price Levels, $1990-2011$.

\begin{tabular}{|c|c|c|c|c|c|c|}
\hline \multirow[b]{2}{*}{ Variable } & \multicolumn{3}{|c|}{ OLS } & \multicolumn{3}{|c|}{ OLS } \\
\hline & Coefficient & & (Std. Err.) & Coefficient & & (Std. Err.) \\
\hline & \multicolumn{6}{|c|}{ Dependent Variable: Count of News Stories Involving Food Riots } \\
\hline Food Price Three-Month Volatility & 0.867 & & $(1.085)$ & & & \\
\hline Cereals Price Three-Month Volatility & & & & -0.117 & & $(0.670)$ \\
\hline Count of News Stories in $t-1$ & 0.057 & $* * *$ & $(0.063)$ & 0.388 & $* * *$ & $(0.063)$ \\
\hline Trend & 0.335 & $* * *$ & $(0.047)$ & 0.346 & $* * *$ & $(0.046)$ \\
\hline Intercept & 0.5703381 & & $(8.727)$ & 1.621 & & $(8.700)$ \\
\hline Number of Observations & & 251 & & & 251 & \\
\hline Monthly Dummies & & Yes & & & Yes & \\
\hline$p$-value (Joint Significance) & & 0.00 & & & 0.00 & \\
\hline$R$-square & & 0.62 & & & 0.62 & \\
\hline
\end{tabular}




\section{Appendix}

Table A1. OLS Estimation Results for the Reduced Form Relationship between Natural Disasters and Political Unrest, $1990-2011$.

\begin{tabular}{lrrr}
\hline Variable & Coefficient & \multicolumn{2}{c}{ (Std. Err.) } \\
\hline \multicolumn{1}{c}{ Dependent Variable: Count of News Stories Involving Food Riots } \\
Count of Natural Disasters & 1.522 & $* * *$ & $(0.355)$ \\
Intercept & 34.142 & $* * *$ & $(8.857)$ \\
\hline Number of Observations & \multicolumn{3}{c}{253} \\
$p$-value (Joint Significance) & 0.01 \\
$R$-square & \multicolumn{3}{c}{0.07} \\
\hline Note: The symbols ***, **, and * respectively denote statistical significance at the 1, 5, and \\
10 percent levels.
\end{tabular}


Table A2. IV Estimation Results for Robustness Checks on the Determinants of Political Unrest Using Alternative Definitions of the Instrumental Variable, 1990-2011.

\begin{tabular}{|c|c|c|c|c|c|c|c|c|c|c|c|c|}
\hline \multirow[b]{2}{*}{ Variable } & \multicolumn{3}{|c|}{$\begin{array}{l}\text { IV Includes Droughts, } \\
\text { Extreme Temperature, } \\
\text { Floods, Insect Infestations, } \\
\text { and Storms }\end{array}$} & \multicolumn{3}{|c|}{$\begin{array}{l}\text { (2) } \\
\text { IV Includes Droughts, } \\
\text { Extreme Temperature, Floods, } \\
\text { and Insect Infestations }\end{array}$} & \multicolumn{3}{|c|}{$\begin{array}{l}\text { IV Includes Droughts, } \\
\text { Extreme Temperature, } \\
\text { and Floods }\end{array}$} & \multicolumn{3}{|c|}{$\begin{array}{l}\text { IV Includes Droughts } \\
\text { and Floods }\end{array}$} \\
\hline & Coefficient & & $\begin{array}{l}\text { (Std. } \\
\text { Err.) } \\
\end{array}$ & Coefficient & & $\begin{array}{l}\text { (Std. } \\
\text { Err.) }\end{array}$ & Coefficient & & $\begin{array}{l}\text { (Std. } \\
\text { Err.) } \\
\end{array}$ & Coefficient & & $\begin{array}{l}\text { (Std. } \\
\text { Err.) } \\
\end{array}$ \\
\hline & \multicolumn{12}{|c|}{ Dependent Variable: Count of News Stories Involving Food Riots } \\
\hline Food Price & 1.562 & $* * *$ & $(0.582)$ & 1.455 & $* *$ & $(0.598)$ & 1.403 & $* *$ & $(0.604)$ & 1.454 & $* *$ & $(0.605)$ \\
\hline Food Price Three-Month Volatility & -6.115 & $* *$ & $(2.832)$ & -5.634 & $*$ & $(2.891)$ & -5.404 & $*$ & $(2.917)$ & -5.631 & $*$ & $(2.922)$ \\
\hline Count of News Stories in $t-1$ & 0.190 & $*$ & $(0.098)$ & 0.203 & $* *$ & $(0.098)$ & 0.210 & $* *$ & $(0.099)$ & 0.203 & $* *$ & $(0.099)$ \\
\hline Trend & 0.232 & $* * *$ & $(0.062)$ & 0.239 & $* * *$ & $(0.062)$ & 0.242 & $* * *$ & $(0.062)$ & 0.239 & $* * *$ & $(0.062)$ \\
\hline Intercept & -136.334 & $* * *$ & $(51.766)$ & -126.908 & $* *$ & $(53.121)$ & -122.395 & $* *$ & $(53.703)$ & -126.847 & $* *$ & $(53.762)$ \\
\hline Number of Observations & \multicolumn{3}{|c|}{251} & \multicolumn{3}{|c|}{251} & \multicolumn{3}{|c|}{251} & \multicolumn{3}{|c|}{251} \\
\hline Monthly Dummies & \multicolumn{3}{|c|}{ Yes } & \multicolumn{3}{|c|}{ Yes } & \multicolumn{3}{|c|}{ Yes } & \multicolumn{3}{|c|}{ Yes } \\
\hline$p$-value (Joint Significance) & \multicolumn{3}{|c|}{0.00} & \multicolumn{3}{|c|}{0.00} & \multicolumn{3}{|c|}{0.00} & \multicolumn{3}{|c|}{0.00} \\
\hline$F$-statistic (Instrument) & \multicolumn{3}{|c|}{19.71} & \multicolumn{3}{|c|}{17.98} & \multicolumn{3}{|c|}{17.31} & \multicolumn{3}{|c|}{17.47} \\
\hline$R$-square & \multicolumn{3}{|c|}{0.60} & \multicolumn{3}{|c|}{0.61} & \multicolumn{3}{|c|}{0.61} & \multicolumn{3}{|c|}{0.61} \\
\hline
\end{tabular}

Note: The symbols $* * *, * *$, and * respectively denote statistical significance at the 1,5 , and 10 percent levels. With respect to the full sample of 253 observations, two observations are lost because food price three-month volatility is calculated using food prices in $t, t-1$, and $t-2$. The $F$-statistic is used to assess whether the instrumental variable is weak (Stock and Yogo, 2002). 
Table A2. IV Estimation Results for Robustness Checks on the Determinants of Political Unrest Using Alternative Definitions of the Instrumental Variable, 1990-2011 (Continued).

\begin{tabular}{|c|c|c|c|c|c|c|c|c|c|c|c|c|}
\hline \multirow[b]{2}{*}{ Variable } & \multicolumn{3}{|c|}{$\begin{array}{c}(5) \\
\text { IV Includes Droughts, } \\
\text { Extreme Temperature, Floods, } \\
\text { Insect Infestations, } \\
\text { and Storms }\end{array}$} & \multicolumn{3}{|c|}{$\begin{array}{c}(6) \\
\text { IV Includes Droughts, } \\
\text { Extreme Temperature, } \\
\text { Floods, and Insect Infestations }\end{array}$} & \multicolumn{3}{|c|}{$\begin{array}{c}(7) \\
\text { IV Includes Droughts, } \\
\text { Extreme Temperature, } \\
\text { and Floods }\end{array}$} & \multicolumn{3}{|c|}{$\begin{array}{c}(8) \\
\text { IV Includes Droughts } \\
\text { and Floods }\end{array}$} \\
\hline & Coefficient & & $\begin{array}{c}\text { (Std. } \\
\text { Err.) } \\
\end{array}$ & Coefficient & & $\begin{array}{l}\text { (Std. } \\
\text { Err.) }\end{array}$ & Coefficient & & $\begin{array}{l}\text { (Std. } \\
\text { Err.) } \\
\end{array}$ & Coefficient & & $\begin{array}{l}\text { (Std. } \\
\text { Err.) } \\
\end{array}$ \\
\hline & \multicolumn{12}{|c|}{ Dependent Variable: Count of News Stories Involving Food Riots } \\
\hline Cereals Price & 1.052 & $* * *$ & $(0.349)$ & 0.970 & $* * *$ & $(0.357)$ & 0.954 & $* * *$ & $(0.369)$ & 0.991 & $* * *$ & $(0.373)$ \\
\hline Cereals Price Three-Month Volatility & -4.865 & $* * *$ & $(1.704)$ & -4.495 & $* * *$ & $(1.736)$ & -4.420 & $* *$ & $(1.786)$ & -4.587 & $* *$ & $(1.803)$ \\
\hline Count of News Stories in $t-1$ & 0.206 & $* *$ & $(0.086)$ & 0.220 & $* *$ & $(0.086)$ & 0.223 & $* *$ & $(0.088)$ & 0.217 & $* *$ & $(0.089)$ \\
\hline Trend & 0.267 & $* * *$ & $(0.052)$ & 0.274 & $* * *$ & $(0.052)$ & 0.275 & $* * *$ & $(0.052)$ & 0.272 & $* * *$ & $(0.053)$ \\
\hline Intercept & -82.968 & $* * *$ & $(29.286)$ & -76.373 & $* * *$ & $(29.899)$ & -75.047 & $* *$ & $(30.821)$ & -78.012 & $* *$ & $(31.133)$ \\
\hline Number of Observations & \multicolumn{3}{|c|}{251} & \multicolumn{3}{|c|}{251} & \multicolumn{3}{|c|}{251} & \multicolumn{3}{|c|}{251} \\
\hline Monthly Dummies & \multicolumn{3}{|c|}{ Yes } & \multicolumn{3}{|c|}{ Yes } & \multicolumn{3}{|c|}{ Yes } & \multicolumn{3}{|c|}{ Yes } \\
\hline$p$-value (Joint Significance) & \multicolumn{3}{|c|}{0.00} & \multicolumn{3}{|c|}{0.00} & \multicolumn{3}{|c|}{0.00} & \multicolumn{3}{|c|}{0.00} \\
\hline$F$-statistic (Instrument) & \multicolumn{3}{|c|}{29.49} & \multicolumn{3}{|c|}{27.35} & \multicolumn{3}{|c|}{25.30} & \multicolumn{3}{|c|}{24.90} \\
\hline$R$-square & \multicolumn{3}{|c|}{0.64} & \multicolumn{3}{|c|}{0.65} & \multicolumn{3}{|c|}{0.65} & \multicolumn{3}{|c|}{0.65} \\
\hline
\end{tabular}

Note: The symbols $* * *, * *$, and * respectively denote statistical significance at the 1,5 , and 10 percent levels. With respect to the full sample of 253 observations, two observations are lost because food price three-month volatility is calculated using food prices in $t, t-1$, and $t-2$. The $F$-statistic is used to assess whether the instrumental variable is weak (Stock and Yogo, 2002). 
Table A3. OLS Estimation Results for a Test of Whether Political Unrest Granger-Causes Food Prices, 1990-2011.

\begin{tabular}{|c|c|c|c|c|c|c|}
\hline \multirow[b]{2}{*}{ Variable } & \multicolumn{3}{|c|}{ (1) } & \multicolumn{3}{|c|}{ (2) } \\
\hline & Coefficient & & (Std. Err.) & Coefficient & & (Std. Err.) \\
\hline \multicolumn{7}{|c|}{ Dependent Variable: Count of News Stories Involving Food Riots } \\
\hline Food Price & -0.658 & & $(1.169)$ & & & \\
\hline Food Price Three-Month Volatility & -2.986 & $* *$ & $(1.377)$ & & & \\
\hline Cereals Price & & & & -0.340 & & $(0.685)$ \\
\hline Cereals Price Three-Month Volatility & & & & -2.556 & $*$ & $(1.378)$ \\
\hline Count of News Stories in $t-1$ & 0.272 & $* * *$ & $(0.065)$ & 0.284 & $* * *$ & $(0.064)$ \\
\hline Trend & 0.317 & $* * *$ & $(0.048)$ & 0.313 & $* * *$ & $(0.046)$ \\
\hline Food Price in $t-1$ & 0.716 & & $(1.162)$ & & & \\
\hline Food Price in $t-2$ & 0.629 & & $(1.159)$ & & & \\
\hline Food Price in $t-3$ & -0.167 & & $(0.745)$ & & & \\
\hline Food Price in $t+1$ & -0.723 & & $(1.200)$ & & & \\
\hline Food Price in $t+2$ & 1.960 & $*$ & $(1.184)$ & & & \\
\hline Food Price in $t+3$ & -1.102 & & $(0.717)$ & & & \\
\hline Cereal Price in $t-1$ & & & & 0.175 & & $(0.676)$ \\
\hline Cereal Price in $t-2$ & & & & 1.390 & $* *$ & $(0.683)$ \\
\hline Cereal Price in $t-3$ & & & & -0.866 & $*$ & $(0.441)$ \\
\hline Cereal Price in $t+1$ & & & & -0.366 & & $(0.677)$ \\
\hline Cereal Price in $t+2$ & & & & 0.755 & & $(0.673)$ \\
\hline Cereal Price in $t+3$ & & & & -0.330 & & $(0.417)$ \\
\hline Intercept & -63.516 & $* * *$ & $(17.603)$ & -36.512 & $* * *$ & $(12.812)$ \\
\hline Number of Observations & & 247 & & & 247 & \\
\hline Monthly Dummies & & Yes & & & Yes & \\
\hline$p$-value (Joint Significance) & & 0.00 & & & 0.00 & \\
\hline$R$-square & & 0.65 & 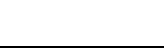 & & 0.66 & \\
\hline
\end{tabular}


Table A4. OLS and IV Estimation Results for Robustness Checks on the Determinants of Political Unrest Using Six-Month Price Volatility, 1990-2011.

\begin{tabular}{|c|c|c|c|c|c|c|c|c|c|c|c|c|}
\hline \multirow[b]{2}{*}{ Variable } & \multicolumn{3}{|c|}{ OLS } & \multicolumn{3}{|c|}{ OLS } & \multicolumn{3}{|c|}{ IV } & \multicolumn{3}{|c|}{ IV } \\
\hline & Coefficient & & $\begin{array}{l}\text { (Std. } \\
\text { Err.) }\end{array}$ & Coefficient & & $\begin{array}{l}\text { (Std. } \\
\text { Err.) }\end{array}$ & Coefficient & & $\begin{array}{l}\text { (Std. } \\
\text { Err.) }\end{array}$ & Coefficient & & $\begin{array}{l}\text { (Std. } \\
\text { Err.) }\end{array}$ \\
\hline & \multicolumn{12}{|c|}{ Dependent Variable: Count of News Stories Involving Food Riots } \\
\hline Food Price & 0.579 & $* * *$ & $(0.154)$ & & & & 0.738 & $* *$ & $(0.319)$ & & & \\
\hline Food Price Three-Month Volatility & -0.557 & & $(0.913)$ & & & & -2.325 & & $(1.763)$ & & & \\
\hline Cereal Price & & & & 0.415 & $* * *$ & $(0.133)$ & & & & 0.632 & $* *$ & $(0.297)$ \\
\hline Cereal Price Three-Month Volatility & & & & -0.363 & & $(0.711)$ & & & & -2.128 & & $(1.667)$ \\
\hline Count of News Stories in $t-1$ & 0.313 & $* * *$ & $(0.064)$ & 0.311 & $* * *$ & $(0.064)$ & 0.264 & $* * *$ & $(0.081)$ & 0.250 & $* * *$ & $(0.086)$ \\
\hline Trend & 0.285 & $* * *$ & $(0.047)$ & 0.290 & $* * *$ & $(0.047)$ & 0.261 & $* * *$ & $(0.055)$ & 0.264 & $* * *$ & $(0.054)$ \\
\hline Intercept & -50.798 & $* * *$ & $(15.847)$ & -32.958 & $* *$ & $(13.209)$ & -62.906 & $* *$ & $(28.433)$ & -46.929 & $* *$ & $(23.058)$ \\
\hline Number of Observations & & 248 & & & 248 & & & 248 & & & 248 & \\
\hline Monthly Dummies & & Yes & & & Yes & & & Yes & & & Yes & \\
\hline$p$-value (Joint Significance) & & 0.00 & & & 0.00 & & & 0.00 & & & 0.00 & \\
\hline$F$-statistic (Instrument) & & - & & & - & & & 30.14 & & & 29.27 & \\
\hline$R$-square & 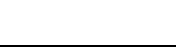 & 0.64 & & & 0.64 & & & 0.62 & & & 0.62 & \\
\hline
\end{tabular}

